\title{
DONATION AND REMOVAL OF ORGANS, TISSUES OR HUMAN CELLS FROM THE DECEASED PERSONS
}

\author{
R. Matefi
}

\section{Ph. D. Lecturer MATEFI ROXANA}

Abstract: This paper proposes an approach to a subject with profound implications, generating a lot of controversy, the donation and removal of organs, tissues and human cells from the deceased persons. There will be analyzed the legal conditions required to be met according to the law for this process to be feasible, not forgetting of that exposure the possible criminal consequences that failure of these conditions could attract.

Key words: donation, removal, deceased person, organ, tissue, human cell, consent.

\section{Introduction}

Death and the legal consequences that it generates has been the subject of numerous doctrinal analysis, likely to reveal the peculiarities of this phenomenon.

"The universal experience of human death generates responses in every medium of individual, social and cultural expression. Laws based on religious or moral principles reflect this conditioning in their approaches to death (...) less attention is paid to the inherent qualities or rights of people than to their property; people are a means by which property is owned, possessed, protected and transferred. Death is considered a legal status. The time of a person's death marks the point at which other legal events occur, such as the inheritance of an estate by survivors or the process of distribution of an estate, a body may (and in a relatively short time must) be buried, cremated or otherwise disposed of in accordance with law (...) it also marks the point under modern legislation at which organs may be recovered for posthumous transplantation. The legal status of death arises when the legal criteria of death are satisfied. The criteria are based on observations that medically qualified persons have the capacity to make, although in many circumstances lay persons could apply the criteria too. Classically, the criteria of death were the cessation of respiration and blood circulation"”.

As for the aspects regarding the inviolability of a person, doctrine makes a clear distinction between a living person and a deceased one, by stating that "even if it is still impregnated with the personality of the person it used to be, a corpse is merely a thing. This does not mean that a corpse does not require special protection. But the notion of inviolability does not have the same meaning whether we are discussing a living person or a deceased person ${ }^{2} "$.

As regards the content of the process of donating vital organs after death "donation of skin, bone, cornea, as well as total body donation for research and teaching. The term is more often used in the context of organ transplantation where large solid organs can be transplanted

\footnotetext{
${ }^{1}$ Bernard M. Dickens, Legal and judicial aspects of post mortem organ donation in Procurement, Preservation and Allocation of Vascularized Organs, Springer Link, p. 343, 344.

${ }^{2}$ T. Prescure, R. Matefi, Civil law. General Part, Hamangiu Publishing House, Bucharest, 2012, p. 307, authors who quote O. Ungureanu, C. Munteanu, Civil law. The person in the regulation of the new Civil Code, Hamangiu Publishing House, Bucharest, 2012, p. 23.
} 


\section{DONATION AND REMOVAL OF ORGANS, TISSUES OR HUMAN CELLS FROM THE DECEASED PERSONS}

into recipients. The declaration of death by neurological criteria takes on special significance in the setting of transplantation because the majority of donors are declared dead by neurologic criteria" ${ }^{3 "}$.

As shown in the doctrine this process of organ transplantation is not new, so ,the miraculous transplantation of organs was spoken about in medieval times, and a 16th century picture by Fernando del Rincon, hanging in the Prato, shows a sacristan whose leg had become gangrenous receiving the healty leag of a black man, presumably a slave ${ }^{4}$.

\section{The legal conditions of donation and removal of organs, tissues or human cells from the deceased persons}

The issue of removing organs from the deceased person is one with profound implications, likely to cause controversy on a doctrine level. Once the new Civil Code came into force, it introduced a section which regulates the respect owed to the deceased person, as the lawmaker found it is necessary to regulate these aspects. Thus, as stated by article 81 of the Civil Code "removing organs, tissues and human cells from the deceased person, whether it is for a therapeutic of scientific purpose, is performed only under the conditions stated by law, with prior written consent of the deceased person, expressed during lifetime or, in lack of, based on the freely expressed consent from the surviving spouse, the parents, the descendents or the collateral relatives until the fourth degree".

This provision regarding the order of the relatives which express consent for the deceased person is regulated in article 147 point 4 of Law no 95/2006 regarding the health reform. The lawmaker expressly regulates the imperative conditions which should be met in order to remove organs from the deceased person.

This procedure is possible only if the deceased person offered consent during lifetime or, in lack of, consent is necessary from the people expressly regulated by the lawmaker, by respecting the outlined order. "By mentioning a specific order of the people who can express consent for removing organs, we can draw the conclusion that relatives of a more distant degree can only express valid consent if the closest relatives are unable to do so (...) if the person who is the closest relative of the deceased refuses removal of organs, consent expressed by a more distant relative is ineffective ${ }^{5 \%}$. As for the form of the consent, it is necessary that it is expressed in writing, as an ad validitatem condition, whether it is a prior consent from the deceased person, or it is provided by the relatives, as pointed out by the lawmaker. Given the implications of this act it was natural for the legislature to impose specific conditions of form which are required to be fulfilled by the document which contain the consent for removal.

The lawmaker also regulated the possibility of the living person to express consent for removal of organs once deceased, by notary consent and registration in the National registry for organ, tissue and human cells donors ${ }^{6}$.

However, if during lifetime, a person expressed its option contrary to organ donation, organ removal is strictly forbidden ${ }^{7}$. The possibility to consent or oppose removal of cells, tissue is qualified by doctrine as a component of a person's right to decide regarding its own body $^{8}$.

\footnotetext{
${ }^{3}$ Encyclopedia of Intensive Care Medicine, Springer Link, p. 1630.

${ }^{4}$ Erich H. Loewy, Textbook of Medical Etichs, Springer Link, p. 109 și urm.

${ }^{5}$ E. Chelaru, Civil law. The person in the regulation of the new Civil Code, C.H. Beck Publishing House, Bucharest, 2012, p. 30.

${ }^{6}$ Article 147, point 5 of Law no 95/2006 regarding the health reform.

${ }^{7}$ See article 147, sixth alignment of Law no 95/2006 regarding the health reform.

${ }^{8}$ E. Chelaru, op. cit., p. 29.
} 


\section{R. Matefi}

The text of article 147 of the Law regarding the health reform makes a distinction between the deceased donor with no heart activity and the deceased donor with some cardiac activity. Thus, the deceased donor with no cardiac activity is, according to point 1 of the previously quoted text of law "the person who has no cardiac or respiratory function, with no possibility of resuscitation and in an irreversible manner, as confirmed by two primary physicians. The confirmation of the deceased donor with no cardiac activity is performed according to the resuscitation protocol, as approved by the health ministry, except for the unequivocal situations"; the deceased donor with cardiac activity is "the person who has no brain function, according to the protocol for declaring a person brain dead, as approved by the health ministry"9.

The lawmaker also states that "declaring a person brain dead is performed by physicians who are not a part of the teams who coordinate, remove or transplant organs, tissues and human cells"10.

The lawmaker limits the performance of this procedure, whether it is for therapeutic or scientific purpose. Thus, the provision of article 141 first alignment of Law no 95/2006 regarding the health reform states that "donation and transplant of organs, tissue or human cells is performed in a therapeutic purpose, by ensuring quality and safety standards in order to protect human health". We must also mention the provision of article 23 of Law no 104/2003 regarding the handling of human corpses and removing organs and tissues from corpses for transplant purposes "the university course of anatomy, pathological anatomy and the corresponding services can take over bodies for scientific and teaching purposes in the following situations:

a) when there is a written prior agreement from the patient or the family;

b) living people can decide that, upon their death, their body will be given to teaching institutions, based on common regulations elaborated by hospitals and universities;

c) unclaimed bodies are given to teaching facilities, according to the provisions of article 17 and $18 "$.

\section{Criminal consequences of not full filling the legal conditions regarding organs' removal and transplant}

Removal or transplant of organs, tissues or human cells require some strict conditions which are expressed by the lawmaker; disrespecting these conditions can cause criminal consequences, whether we are discussing removal or transplant from living donors or from deceased persons.

Thus, according to the provisions of article 155 of Law no 925/2006 regarding the health reform "removal of organs when it compromises an autopsy, as requested by law, is a crime and is punished with imprisonment from 6 months to 3 years or a fine". Donation of organs, tissue or human cells, in order to obtain material benefits, for himself or for another person, is also a crime and is punished with imprisonment from 3 months to 2 years or a fine $^{11}$.

It is also a crime to force a person to donate organs, tissue or human cells and it is punished with imprisonment from 2 to 7 years and the forbidding of some rights ${ }^{12}$.

"The publishing or advertising of notices regarding organ donation or donation of tissue or human cells, donation which would be performed in order to obtain material benefits

\footnotetext{
${ }^{9}$ Article 147, point 2 of Law no 95/2006 regarding the health reform.

${ }^{10}$ Article 147, point 4 of Law no 95/2006 regarding the health reform.

11 Article 156, first alignment of Law no 95/2006 regarding the health reform.

12 Article 156, second alignment of Law no 95/2006 regarding the health reform.
} 


\section{DONATION AND REMOVAL OF ORGANS, TISSUES OR HUMAN CELLS FROM THE DECEASED PERSONS}

for that certain person of for another person" is also a crime as regulated by the lawmaker and is punished by imprisonment from 6 months to 3 years or a fine ${ }^{13}$.

Other crimes sanctioned by the lawmaker are "organizing or performing organ, tissue or human cells removal for transplant, in order to obtain material benefits for the donor or organizer"14 as well as buying organs, tissue or human cells in order to resell it" ${ }^{15}$. In both cases, the punishment is imprisonment from 2 to 7 years and the forbidding of some rights. The attempt is also punished.

\section{Conclusions}

As is results from this analysis, the donation and removal of organs, tissues and human cells from deceased persons can be done only under the conditions expressly laid down by the legislator. This procedure is not possible if the deceased person did not offered his consent during lifetime or, in lack of, the consent is necessary from the people expressly regulated by the lawmaker, namely the surviving spouse, the parents, the descendents or the collateral relatives until the fourth degree, respecting this order. As for the form of the consent, it is necessary that it is expressed in writing, as an ad validitatem condition.

\section{Bibliography}

Law no 104/2003 regarding the handling of human corpses and removing organs and tissues from corpses for transplant purposes.

Law no 95/2006 regarding the health reform.

E. Chelaru, Civil law. The person in the regulation of the new Civil Code, C.H. Beck Publishing House, Bucharest, 2012.

Bernard M. Dickens, Legal and judicial aspects of post mortem organ donation in Procurement, Preservation and Allocation of Vascularized Organs, Springer Link.

T. Prescure, R. Matefi, Civil law. General Part, Hamangiu Publishing House, Bucharest, 2012.

O. Ungureanu, C. Munteanu, Civil law. The person in the regulation of the new Civil Code, Hamangiu Publishing House, Bucharest, 2012.

\footnotetext{
13 Article 156, third alignment of Law no 95/2006 regarding the health reform.

${ }^{14}$ Article 157, first alignment of Law no 95/2006 regarding the health reform.

${ }^{15}$ Article 157, second alignment of Law no 95/2006 regarding the health reform.
} 